\title{
An Analysis of the First Language Acquisition: A Two Years Girl
}

\author{
Endah Ratnaningsih \\ Tidar University, Magelang \\ endahratna@untidar.ac.id
}

\begin{abstract}
As a natural process, human innateness understood as the ability in acquiring first language since birth. First language acquisition is related to this field of study. This study will focus on language acquisition of a two years girl who become the object of observation. However, the understanding of language acquisition and learning, then what factors are associated with language acquisition are regarded to be necessary to explain. Furthermore, on the discussion part, the analysis of the language acquisition on the object observed, both in terms of phonology, lexical, pragmatic, and the factors that influence the process of first language acquisition for the object observed are disscussed.
\end{abstract}

Key words: first language acquisition, lexical acquisition, pragmatic acquisition

\section{A. INTRODUCTION}

Since birth, humans have an innate tool which is very important and sophisticated called the Language Acquisition Device (LAD). This default device allows humans acquiring language since birth. In other words, human beings will be able to speak inexorably to not acquire language. This may imply that language acquisition in humans in the process is natural and unintentional. As expressed by Chomsky that humans from birth will learn the language by itself. Chomsky (2004) in Da Cruz (2015: 6) argues that children's ability to learn language is due to a genetically programmed organ that is located in the brain. Once children are born and are involved in linguistic environments, they immediately start to develop a language.

Before discussing further, it is needed to know the differences between first language and second language. The first language is a language that is firstly received since the children born. The first language commonly called the mother tongue. While a second language is a language that is obtained after mastering the first language and in general this type of language is a foreign language.

In connection with the development of language needs, it is needed to realize that humans need to improve language skills. Human language skills can be improved through two ways, namely acquisition and learning. Acquisition is the process to get a language without deliberate action (unknowingly), usually unstructured, taking place in society, informal, referring to the demands of communicating, and have social consequences (related to the community or neighborhood). That will be different with learning. Learning is the process of getting a language which is deliberate, structured, formal, competency as a major capital, took place in the class, referring to the educational demands, and the knowledge.

This study will focus on language acquisition in a two years girl who become the object of observation. However, the understanding of language acquisition and learning, then what factors are associated with language acquisition are regarded to be necessary to explain. Furthermore, on the discussion part, the analysis of the language acquisition on the object observed, both in terms of phonology, lexicon, and 
pragmatic; and the factors that influence the process of first language acquisition for the object observed are disscussed.

\section{B. THEORETICAL REVIEW ACQUISITION AND LANGUAGE LEARNING}

Language acquisition has a close connection with the human ability to create the perception and understanding the speech of others. Moreover, a child is able to produce speech or speech if he knows the rules derived from childhood (Soenjono, 2010: 225). Language acquisition is one of humankind's most impressive cognitive feats. A 6-month-old can do little more than babble, but by 2 or 3 years of age, children show generative knowledge of the patterns of their language-that is, they can extend the words they hear to new situations, and they can use grammatical constructions in new contexts (Gentner \& Namy, 2006: 1).

Krashen (1982: 10) put the idea of two separate systems as the subordinated performances of a second language. The first system is an acquisition system which takes place naturally when a person receives a fairly comprehensive input, with a low filtration levels, and the focus of language learning is communication and the important uses of language. If all these criteria are completed, the language enters the learners LAD and obtained in the brain, all of which is an unconscious process. The benefits of acquiring a language is that the language be part of the linguistic system of learners and can be automatically used in conversations and communications with the target culture.

The learning system is activated when the learners are aware of a language and focused on the form and the rules of language (Krashen, 1982: 10). Language learning encourages students or learners to focus on editing and planning of a language rather than communicating with the language. Learning more often take place based on grammar, repetition and conditioned by the type of instructional practice. Although learning is an important aspect in second language acquisition, Krashen (1982: 11) believes that the usefulness of a language that is really for communicative purposes, language learners should first acquire language before learning was introduced.

Talking about language acquisition in this study in which the little girl being observed acquired more than one language, it is important to know that this language acquisition will be closely related to culture. As proposed by Nguyen \& Ahmadpanah (2014: 5) that language and culture are intertwined, such that the order in which two languages are learned is linked to whether the corresponding cultures are seen as distinct versus fused.

\section{LANGUAGE ACQUISITION AFFECTING FACTORS}

There are several factors that affect language acquisition. These factors include the linguistic environment (language environment), neurological aspects, routines, and patterns.

The person's speed in learning or language acquisition depends on the ability of the person and the environment in which he or she lives. Language environment is everything around the learners, both audible and visible. In general, the language environment can be divided into two, namely (1) a formal environment or artificial that is found in the learning process; (2) informal or natural environment, which is found in the life of society (Krashen, 1982: 40).

Factors which are also very important in language acquisition is neurological factors, the relation between the human brain and the language lateralization. There 
are several hypotheses submitted by Lenneberg (Krashen, 1981: 76), linked to the lateralization, such as lateralization period which occurred when the baby is still in the womb, when the children are older than 5 years, and at puberty.

Routines and patterns are usefull to build social relationship and act as intake in the process of creative construction. However, this intake is not enough for the successful of language acquisition. Language acquisition, will be more successful by providing input where the routines and patterns have a small but important role in language acquisition.

\section{RESEARCH METHOD}

This was a case-study on the first language acquisition. The main participant of this reserch was a two years girl. The other participants were the parents, grandparents, aunt, and housemaid. The data was taken through some observations.

\section{DISCUSSION}

\section{THE LANGUAGE ACQUISITION FACTORS ANALYSIS}

The participant of the study on observing this first language acquisition is a little girl, at the age of two years. She is acquiring three languages as well as a first language. Those three languages are Javanese, Bahasa Indonesia, and English. Those three languages she got from the languae used by the caretakers speech or language caregivers ( in this study they are people around the object of the study, grandparents, father, mother, aunt, etc.).

She obtained Javenese when she communicates with the grandparent, mother, and her aunts. She received Bahasa Indonesia when communicating with her father; while English she received from her aunt. In terms of the first language acquisition, especially English, she has been able to understand and pronounce words or simple phrases, such as thank you, please, sit down, beautiful, star, and so forth.

In this discussion, the role of the factors related to language acquisition which has been mentioned on the theoretical review will be discussed in relation to the first language acquisition experienced by the little girl observed.

The first factor that affects the research object's first language acquisition is environment. She acquires the first language through informal environment (the natural environment or without planning as in a formal environment). She acquires the first language from the caretaker speech and by utilizing the linguistic environment in the form of media, such as listening to songs in English.

An important thing that can be noted based on the observation, the little girl who is being observed was able to quickly communicate/capture the intent conversation with others. Unlike most children at her age who tend to still fun to play and have its own world, so they less readily in responding their interlocutor. If it is associated with this writer's experience, it can be concluded that the linguistic environment greatly contributes to the language acquisition. First language acquisition, especially for the little girl observed, can be seen more contributed by informal environment. In addition, the first language acquisition process in children tend to be fast and children are able to pronounce the language they acquired native likely.

The second factor that plays a role in the first language acquisition, especially for the little girl observed, is a neurological factor. Based on the writer's observation, lateralization period are likely to be at the time of children aged 2 to 12 years (before puberty ended). The reason is unchangeable because based on the writer's experience to the little girl observed, it was demonstrated that the process of lateralization occurred during this period. Nowadays, the little girl observed almost 2 years old, she 
acquires three languages as her first language. Those three language is Javanese, Bahasa Indonesia, and English.

Routines and patterns is the third factor that plays a role in the first language acquisition, especially for the little girl observed. An evidence for the concept of routines and patterns that exist in the first language acquisition experienced by the little girl observed is when the writer pays attention to that little girl in using routines. For example, the phrase "good morning", good afternoon, and good evening. For the very early moment, the writer only uttered those sentences repeatedly without explaining the word can be replaced by the word "morning, afternoon, and evening." However, as the time goes by, the little girl observed was able to replace those words in accordance with the current state of the day by itself (the creative process). To sum up, routines occurs before patterns.

\section{FIRST LANGUAGE ACQUISITION ANALYSIS}

The writer observed the language skills and social abilities of the little girl obseved for a few days. Here is some conversations conducted by the little girl observed in daily life.

\begin{tabular}{|c|c|}
\hline Observation Date & Data \\
\hline Sunday, January 1, 2017 & $\begin{array}{l}\text { Kakek: arep ngandi Da? } \\
\text { V: nang Ségan( maksudnya Seyegan). } \\
\text { Kakek: nang rumahé sôpô? } \\
\text { V: mbah Ségan yô. } \\
\text { Kok wis mantuk, oleh-oleh apa Da, } \\
\text { ora..ora oleh-oleh, mung salak. } \\
\text { Nang tempate mbah Segan ono sopo wae Da? } \\
\text { Dek Yaya (: Zahra), mas Fae. } \\
\text { Trus bobok karo sopo mau bengi? } \\
\text { Karo mbah Segan. } \\
\text { Mbah kakung? } \\
\text { Udu yo. Karo mbah uti kok. }\end{array}$ \\
\hline Sunday, January 8, 2017 & $\begin{array}{l}\text { Saat itu siang hari. V berbincang dengan mbah uti } \\
\text { Mbah uti, ngko ndak 'kowrok' (maksunya: 'krowok' / gigi } \\
\text { berlubang) } \\
\text { Uti: udu kowrok da, tapi krowok.. } \\
\text { V: ora yo...mbah uti ki bohong } \\
\text { Uti: kok bohong, keliru to da maksudmu? } \\
\text { V: ora mbah...mbah uti ki bohong...V tetap kekeh dan } \\
\text { menganggap keliru sebagai bohong. }\end{array}$ \\
\hline Friday, January 132017 & $\begin{array}{l}\text { V: mbah...mbah, Toibah. (sambil menunjuk pintu). } \\
\text { (keterangan akan dipaparkan pada analisis selanjutnya) }\end{array}$ \\
\hline Friday, January 132017 & $\begin{array}{l}\text { V: Wih, meong. } \\
\text { P: Opo Da? } \\
\text { V: Kae meong. } \\
\text { P: Warnane po Da? } \\
\text { V: Ireng. Kok unak-unuk. } \\
\text { P: Nang endi? } \\
\text { V: Kae nang omah ngarep. }\end{array}$ \\
\hline $\begin{array}{l}\text { Saturday, January 14, } \\
2017\end{array}$ & $\begin{array}{l}\text { Saat itu } V \text { sedang menyapa adiknya, } L \text {, yang belajar } \\
\text { berjalan. }\end{array}$ \\
\hline
\end{tabular}




\begin{tabular}{|c|l|}
\hline & V: Adek...adek...mau ngapain di situ? \\
& MB: (dijawab oleh mbah putri) Mau jalan-jalan mbak. \\
& V: Jalan-jalan kok di situ. \\
\hline Saturday, January 14, & V: mbah.... \\
& MB: Ngopo? \\
& V: mbah, Lek I ki ora sido moto. \\
& MB: Lha ngopo? \\
& V: Tekne ki peteng \\
\hline Sunday, January 15, & MB: Wah, V wis iso numpak pit. \\
& V: Lha iyo yo. \\
& V: Ki bola-bali. \\
& V: Iso tangan siji to mbah? He'em to mbah? \\
& MB: Iyo. \\
\hline Sunday, January 15, & Saat itu V dan peneliti sedang menyaksikan sebuah film. \\
& V: Lek, kuwi akuriume koyo ngono. \\
& P: apa Da? \\
& V: akurium. \\
& P: akurium? Oh, akuarium? \\
& V: He'em \\
\hline
\end{tabular}

Note: $\mathrm{V}$ refers to the little girl observed; $\mathrm{P}$ refers to the researcher; $\mathrm{MB}$ refers to grandparent

\section{Phonological Acquisition at the Age of Two}

The phonological development can be regarded as segmental which involve consonants and vowels, and the suprasegmental development. Based on the writer's observation, that little girl was able to pronounce all the letters correctly, both consonants and vowels. However, the pronunciation of the letter [f], that little girl tends to pronounce by using Javanese accent. An example can be read below.

V: mbah, Lek Ita ki ora sido moto.

Regarding to trill sound of [r], $\mathrm{V}$ has been able clearly to pronounce it. However, there will be a reversal pronunciation in the pronunciation production process. Further example can be read below.

Saat itu siang hari. $V$ berbincang dengan mbah uti

V: Mbah uti, ngko ndak 'kowrok' (maksudnya: 'krowok' / gigi berlubang)

Uti: udu kowrok da, tapi krowok.

Additionally, $\mathrm{V}$ actually be able to pronounce the sound $[\mathrm{r}]$ correctly, but she did not want to use it, as in the pronunciation of the word uti to refer grand mother. Furthermore, according to the conversation dated on January 15, 2017, V said 'akurium' for calling 'aquarium.'

Regarding the consonant cluster, $\mathrm{V}$ has been able to pronounce the consonant cluster [mb], the word mbah. Further, from the aspect of suprasegmental development, that little girl has been able to pronounce most of the words, either dissyllabic or polysyllabic correctly.

\section{Morphosyntax Acquisition at the Age of Two}

The little girl observed in this research experienced a morphological developmental which is related to the kinds of words, such as verb sit, fear, and so on. Furthermore, it can be read in the presented data, that little girl able to do reduplication to lower the syntactic category. From these data it can be seen that the little girl uses a sound copying reduplication, such as unak-unuk and bola-bali; unak- 
unuk means the way cat walks and bola-bali means an alternate activity or repetitive activity.

The syntactic development that can be observed is the development of a noun phrase. The little girl has been able to make a noun phrase, such as the little girl counts the number of people who are at home. Then she said "nang omah saiki ana empat," which means that there are four persons in the house.

\section{Lexical Acquisition}

In the case of the lexical acquisition, the little girl has been able to make generalizations about things. Furthermore, in terms of the development of pronouns, the little girl already use the words, such as saya, aku, kowe, and bocah-bocah (for pointing many people).

\section{Pragmatic Acquisition}

According to Jucker (1998) in Dardjowidjojo (2010: 275), pragmatic refers to the study of interaction meaning which include the meaning and contexts in which the speeches are produced. In relation to the definition, based on the observation of the little girl, the researcher concludes that the little girl-observed has been able to communicate well, the rules regarding to the speech turns can be controlled well. That little girl also able to communicate appropriately (connected). That little girl has been able to communicate or get the meaning or message of the conversation occurred. Her attitude is different from most children in her age who tend to focus on their own world, without caring the surrounding.

\section{CONCLUSION}

The conclusion that can be drawn based on this study can read as follows.

1. There were three languages became the litle girl first languages, Javanese, Bahasa Indonesia, and English.

2. There were three factors influenced the little girl first language acquisition, environment, neurology, and routines.

3. The little girl first language acquisition has developed. That little girl has been able to communicate and interact at the same time in responding the environment.

\section{REFERENCES}

Dardjowidjojo, Soenjono. 2010. Psikolinguistik. Jakarta : Yayasan Obor Indonesia.

Da Cruz, Zulaia Johnston. 2015. First language acquisition: Is children's knowledge of language innnate? Univesity of Iceland: School of Humanities, Department of English.

Gentner, D. \& Namy, L.L. 2006. Analogical processes in langugae learning. Journal of Current directions in psychological science, Vol. 15, No. 6, retrieved on February 2, 2017.

Krashen, Stephen D. 1981. Second Language Acquisition and Second Language Learning. California: Pergamon Press. 
Ratnaningsih/ An Analysis of the First Language Acquisition: A Two Years Girl

Krashen, Stephen D. 1982. Principles and Practice in Second Language Acquisition. University of Southern California.

Nguyen, A.D. \& Ahmadpanah, S.S. 2014. The interplay between bicultural blending and dual language acquisition. Journal of Cross-Cultural Psychology, Vol. 45(8) pp. 1215-1220, jccp.sagepub.com, retrieved on February 2, 2017. 